\title{
An Investigation into Social Studies Teachers' Self-Efficacy Perceptions about Basic Skills in the Social Studies Curriculum
}

\author{
Mustafa ŞEKER ${ }^{1}$ \\ Ylldız Technical University, Istanbul, TURKEY
}

${ }^{1}$ Associate Professor. Yıldız Technical University, Faculty of Education, Department of Turkish and Social Sciences, Davutpaşa Campus, Esenler, Istanbul, TURKEY. mseker[at]yildiz.edu.tr. ORCID: 0000-0002-6397-0579

\begin{abstract}
The aim of this study is to investigate the self-efficacy perceptions of Social Studies teachers about the basic skills in the 2018 Social Studies curriculum. In Turkey, according to changes made in the Social Studies curriculum in 2018, Social Studies lessons are given to students in the 4th, 5th, 6th, and 7th grades, and comprise 27 basic skills, This study investigated the self-efficacy perceptions of 143 Social Studies teachers working in Istanbul province. The study found that the majority of teachers felt themselves to be "inefficient" in the following skills: research, perception of change and continuity, critical thinking, entrepreneurship, legal literacy, collaboration, using evidence, perceiving space, political literacy, drawing and interpreting table, graphics and diagrams, innovative thinking, and perceiving time and chronology. Additionally, it was found that the teachers believed that they were at a "good" or "very good" level of efficacy concerning the following skills: environmental literacy, digital literacy, empathy, financial literacy, observation, map literacy, communication, stereotypical judgment and prejudice, decision making, location analysis, media literacy, self-control, problem solving, social participation, and the correct, beautiful, and effective use of Turkish. This indicates that most Social Studies teachers who participated in the study perceived themselves as being at a positive/efficient level in 16 of the 27 skills. Therefore, the efficacies of Social Studies teachers regarding the basic skills of the 2018 Social Studies curriculum could provide opportunities for these individuals to apply effective strategies, methods, and techniques for their students.
\end{abstract}

\section{Keywords}

Social Studies, Skill, Self-Efficacy, Geography Teaching Skills, History Teaching Skills

To cite this article: Şeker, M. (2021). An investigation into social studies teachers' self-efficacy perceptions about basic skills in the social studies curriculum. Review of International Geographical Education (RIGEO), 11(2), 317-334. doi: 10.33403rigeo.753880 
Throughout history, humans have been investigating and questioning everything that happens around them. With a constant curiosity, they have tried to make sense of events, facts, and formations by analyzing their consequences and attempting to understand how they can be a part of the process within such a framework. The main purpose of our education system is to raise individuals with knowledge, skills and behaviors integrated with our values and competencies. While trying to gain knowledge, skills and behaviors through curricula, our values and competencies function as a link and horizon that establish the integrity between these knowledge, skills, and behaviors (MEB, 2018).

As humans are social beings, it is important that they are aware of what is happening around them while also adapting to their environment. Every kind of event, change, and development of the environment in which humans live influences each individual, either directly or indirectly. For this reason, teaching current issues is important and so schools, social studies courses, and textbooks are crucial in fulfilling this task (Taşkın \& Memişoğlu, 2019). Due to the melting of the various subdisciplines of Social Sciences into a single Social Studies 'pot', the field is one that involves raising individuals with citizenship consciousness, which it does continue on with using the constructivist framework of the 2005 Social Studies program or curriculum.

According to Erden (undated), Social Studies is a field in which students gain basic knowledge, skills, attitudes, and values about social life-based on the knowledge formed by sub-disciplines belonging to Social Sciences-so that they are able to raise good and responsible citizens in primary education.

The functionality of the acquired knowledge and skills in practical life has an important place in the acquisition of new knowledge. If information is supported with up-to-date and functional new information, it will also serve to form enriching new resources. Therefore, feeding the acquired knowledge from strong sources may also have an effect on the transformation of that knowledge into skills and attitudes.

It is essential that students internalize and make inferences from the knowledge they gain from various sources in Social Studies classes. Due to this feature of Social Studies classes, teaching methods are preferred that transform knowledge to skills and that enable internalization rather than methods that transmit knowledge alone (Sever et al., 2009).

It may be an effective approach to strengthen the cognitive and social aspects of the students so that they can use the information functionalized using different strategies, methods and techniques in the future. In fact, strong emphasis on emotional, moral, language and social development as well as cognitive aspects can be considered more important on the transformation of knowledge into skills.

Today, through training programs developed and based on constructivist philosophy, raising individuals who develop their own knowledge and skills, and who do not only learn within the cognitive field but also in the social, emotional, moral, and physical development fields have become important. Accordingly, learner characteristics have gained greater importance in the education system of Turkey. An individual's belief in themselves and their own judgment regarding their 
ability to perform a certain performance successfully is called self-efficacy. Selfefficacy belief is not only an important determinant of academic success in school life, but also an important skill that individuals can use throughout their lives; not only does self-efficacy form an important part of motivation and behavior, it also affects actions that can change people's lives (Arseven, 2016).

The concept of self-efficacy concerns the judgment of an individual, in accordance with their abilities for organizing and executing activity plans; these are necessary to reveal the specified performance diversity and beliefs in those abilities that will enable them to manage what is expected of them (Bandura, 1986; 1995). Selfefficacy is the belief that one can accomplish a particular task; a belief that affects whether or not that person attempts to act on the task, their perseverance in this behavior, their motivation toward that behavior and, consequently, their performance (Kotaman, 2008). Self-efficacy is an individual's judgment and belief of how they can be successful in overcoming difficult situations they might encounter in the future. Self-efficacy, as one of the important motivations behind human behavior, has an important place in the mental health of children and adolescents (Yardimci \& Primekal, 2010).

While 15 skills were included in the 2005 Social Studies curriculum in Turkey, it was determined that some of these skills should be removed; the remaining 13 skills were then included in the 2017 draft curriculum, with an additional nine skills being added to the 2017 draft curriculum. Considering both the 2005 and 2017 programs and the content dimensions of both, it can be said that both documents have evidence of using Bruner's spiral (spiral-helical) programming approach along with a collective teaching approach. The three skills recently encountered in the 2017 draft curriculum include digital literacy, financial literacy, and media literacy skills. Accordingly, it is thought that these skills can overcome the limitation and deficiency of the 2005 Social Studies program, which aims to raise effective citizens (Tay, 2017).

Concerning the functioning of the curriculum, it is important to determine the extent to which common and lesson-specific skills found within the Secondary School Social Studies Curriculum (5th-7th Grade) are included in learning outcomes and activities, together with identifying which of these skills are more prominent and the criteria for the distribution of such skills regarding these outcomes and activities (Aydemir \& Adamaz, 2017). The education system is not only a structure for academic success and provision of certain knowledge, skills, and behaviors raising individuals who have adopted the basic values is its primary duty and the system must be able to influence the values, habits, and behaviors of new generations. The education system fulfills its function within the framework which has the aim of gaining values. "Educational program" or curriculums are formed by taking all the elements of the education system such as learning and teaching environments, educational tools, extracurricular activities, and legislation into account (MEB, 2018).

The teacher is the architect of the whole process. It is important for Social Studies teachers to develop themselves, especially in skills, for the healthy running of the process and admirable education. For this reason, a comprehensive study was 
needed in order to know the levels of the teachers who teach Social Studies and to do skill-oriented studies accordingly.

\section{Aim}

The Social Studies Curriculum aims to teach the following skills in accordance with the scope of this course and the Turkey Framework of Qualifications (TFQ). These skills are Research, Environmental literacy, Perception of change and continuity, Digital literacy, Critical thinking, Empathy, Financial literacy, Entrepreneurship, Observation, Map literacy, Legal literacy, Communication, Cooperation, Recognizing stereotypes and prejudice, Using evidence, Decision making, Location analysis, Media literacy, Perceiving space, Self-control, Political literacy, Problem solving, Social participation, Drawing and interpreting tables, graphics, and diagrams, The correct, beautiful, and effective use of Turkish, Innovative thinking, and Perception of time and chronology.

One of the primary objectives of the Secondary School Social Studies Curriculum is to help individuals acquire common and lesson-specific skills to aid them in becoming active and participatory citizens (Aydemir \& Adamaz, 2017).

The aim of the current study is to investigate the self-efficacy perceptions of Social Studies teachers about the basic skills in the Social Studies Curriculum. Within the framework of these purposes, the following sub-problems have also been investigated:

1. What are the perceptions of Social Studies Teachers about Self-Efficacy of the Basic Skills in the Social Studies Program?

2. In which basic skills do Social Studies Teachers consider themselves more efficient?

3. In which basic skills do Social Studies Teachers consider themselves more inadequate?

4. In which field(s) of basic skills do Social Studies Teachers consider themselves more competent?

5. In which field(s) of basic skills do Social Studies Teachers consider themselves more inadequate?

6. What precautions should Social Studies Teachers take if they see themselves as inadequate in terms of basic skills?

\section{Methodology}

This section explains the research model, research model, universe, sample and data-collection tool used in this research.

\section{Research Design}

This study was conducted using a quantitative research design and survey model. This model is therefore an approach that aims to describe a situation that either previously existed or that currently exists. The event, person, or object that is the subject of the research is defined without any change. No effort is made to change or influence them in any way (Karasar, 2007: 77). This study is suitable for the screening model as it tries to reveal the self-efficacy of Social Studies teachers in the 
skills indicated in the curriculum. Because scanning models are a research approach that aims to describe a past or present situation as it is (Sönmez \& Alacapınar, 2011).

Data collected in this study were obtained from the answers given by Social Studies teachers when responding to the study questionnaire. The answers given by the teachers were analyzed and interpreted with SPSS 20 . With the data obtained from the scale, the level of readiness of the teachers for the acquisition of skills and their situation on these issues were revealed.

\section{Working Group and Sample}

For this study, Istanbul province was chosen as the location for obtaining a working or participant group for the study. Therefore, the study sample comprised 143 Social Studies teachers working in secondary schools across the Istanbul province. As the study investigates the self-efficacies of teachers regarding the basic skills of the program, findings obtained from the sample were evaluated to meet the aim of the study. The selection of teachers for the sample occurred by a randomsampling method. Especially, undergraduate Social Studies teachers took part in the research.

\section{Data Collection Instrument and Process}

A questionnaire, a Likert type scale, was used to collect the study data. The 143 Social Studies teachers were asked about their self-efficacy status concerning the 27 basic skills included in the program or curriculum. Their answers were then synthesized and evaluated.

Questions about the teachers' basic skills in the program were prepared accordingly so to obtain the required findings. The prepared questions were sent to ten Social Studies teachers and three academics for examination. The questions were revised based on the feedback from teachers and academics. According to Büyüköztürk (2012), the scope and face-validity of the scales can be obtained through expert opinions.

\section{The Study Group}

This study, which was conducted to determine the opinions of social studies teachers on the self-efficacy of the skills indicated in the program, was carried out with Social Studies teachers working in 7 districts of the Istanbul province (Güngören, Bağcılar, Esenler, Bahçelievler, Pendik, Ümraniye, Üsküdar) during the spring semester of the 2019-2020 academic year. The self-efficacy scale developed by the researcher was applied to 143 Social Studies teachers. The validity and reliability analyses of the scale were made.

\section{Data Collection Tools}

In the research, quantitative research methods were used, and it was decided to apply the "Self-Efficacy Scale" developed by the researcher. The skills in the research were taken from the Social Studies Curriculum. Skills were directed to teachers. Expert opinions from the field of Social Studies teaching were also consulted. In the study, a 5-point Likert type rating (very inadequate, insufficient, fair, good, very good) scale was used. Scale item scores were graded as 1, 2, 3, 4, 5 and applied to 
143 teachers. The Kaiser-Meyer Olkin (KMO) co-efficient was found 0.89 to reveal the construct validity of the scale. In order for this specified value to be acceptable, the specified limit must be above 0.50 (Büyüköztürk, 2012). Since it is a Likert-type grading scale, the internal consistency measure "Cronbach Alpha Reliability Coefficient" was used to calculate the reliability. A Cronbach Alpha Reliability Coefficient below "0.40" means that the scale is "unreliable", "low reliability" between "0.40-0.59", "reliable" between "0.60-0.79" and "highly reliable" between "0.80-1.00". (Tezbaşaran, 1997). The Cronbach Alpha Reliability Coefficient of the "Self-Efficacy Scale" used in the study was calculated at 0.83. According to the analysis results obtained, it can be said that the scale has a high level of reliability in terms of internal consistency.

\section{Data Analysis}

Descriptive statistical values of the scale items were examined (frequency and percentage). The survey data obtained in this study were analyzed using the SPSS 20 program. For the analysis of the data, teachers' responses to questions about each skill were evaluated in terms of the percentage/frequency and arithmetic mean values. As the teachers' perceptions about basic skills were measured during the research process, their demographic status was not taken into account.

\section{Findings}

Social Studies teachers who participated in this study were asked about the level of ability in which they saw themselves regarding various basic skills of the program. The following results arose.

Table 1

Social Studies Teachers' Self-Efficacy Opinions about the Basic skills in the Social Studies Program

\begin{tabular}{|c|c|c|c|c|c|c|c|c|}
\hline Basic Skills & & $\begin{array}{l}\text { Very } \\
\text { inefficie } \\
\text { nt }\end{array}$ & Inefficient & $\begin{array}{l}\text { Moder } \\
\text { ate }\end{array}$ & Good & $\begin{array}{l}\text { Very } \\
\text { good }\end{array}$ & $\begin{array}{c}\text { Tot } \\
\text { al }\end{array}$ & $\overline{\mathrm{x}}$ \\
\hline \multirow{2}{*}{ Research } & f & 25 & 15 & 53 & 25 & 25 & 143 & \multirow{2}{*}{3.95} \\
\hline & $\%$ & 17.5 & 10.5 & 37.1 & 17.5 & 17.5 & 100 & \\
\hline \multirow{2}{*}{$\begin{array}{l}\text { Environmental } \\
\text { literacy }\end{array}$} & $\mathrm{f}$ & 2 & 15 & 25 & 52 & 49 & 143 & \multirow{2}{*}{3.90} \\
\hline & $\%$ & 1.4 & 10.5 & 17.5 & 36.4 & 34.3 & 100 & \\
\hline \multirow{2}{*}{$\begin{array}{l}\text { Perception of } \\
\text { change and } \\
\text { continuity }\end{array}$} & $\mathrm{f}$ & 7 & 5 & 54 & 39 & 38 & 143 & \multirow[b]{2}{*}{3.70} \\
\hline & $\%$ & 4.9 & 3.5 & 37.8 & 27.3 & 26.6 & 100 & \\
\hline \multirow{2}{*}{ Digital literacy } & f & 8 & 8 & 35 & 54 & 38 & 143 & \multirow{2}{*}{3.79} \\
\hline & $\%$ & 5.6 & 5.6 & 24.5 & 37.8 & 26.6 & 100 & \\
\hline Critical & $f$ & 25 & 50 & 25 & 17 & 26 & 143 & \multirow{2}{*}{3.60} \\
\hline thinking & & 17.5 & 35.0 & 17.5 & 11.9 & 18.2 & 100 & \\
\hline
\end{tabular}

For the Research skills, one of the program's basic skills, teachers responded that they mostly saw themselves at a "moderate" (37.1\%) level. Comparatively, teachers reported that they were at a "good" (36.4\%) level regarding environmental literacy skills; at a "moderate" (37.8\%) level in their perception of change and continuity skills; at a "good" (37.8\%) level for digital literacy skills; and at an "inefficient" 
SSeker, M. (2021). An Investigation into Social Studies Teachers'Self-Efficacy Perceptions about Basic..

(35.0\%) level in terms of critical thinking skills. According to the results, a majority of teachers reported they were at a "good" or "moderate" level for research, environmental literacy, perception of change and continuity, and digital literacy skills, and at an "efficient" level for critical thinking skills.

Table 2

Social Studies Teachers' Self-Efficacy Opinions about Basic Skills in the Social Studies Program

\begin{tabular}{llccccccc}
\hline \multirow{2}{*}{ Basic Skills } & & $\begin{array}{c}\text { Very } \\
\text { ineffic } \\
\text { ient }\end{array}$ & $\begin{array}{c}\text { Inefficie } \\
\text { nt }\end{array}$ & $\begin{array}{c}\text { Moderat } \\
\mathrm{e}\end{array}$ & Good & $\begin{array}{c}\text { Very } \\
\text { good }\end{array}$ & Total & $\overline{\mathrm{x}}$ \\
\hline \multirow{2}{*}{ Empathy } & $\mathrm{f}$ & 7 & 8 & 31 & 60 & 37 & 143 & 3,84 \\
& $\%$ & 4.9 & 5.6 & 21.7 & 42 & 25.9 & 100 & \\
\hline \multirow{2}{*}{ Financial } & $\mathrm{f}$ & 28 & 5 & 15 & 52 & 43 & 143 & \multirow{2}{*}{3.87} \\
\hline \multirow{2}{*}{ Entrepracy } & $\%$ & 19.6 & 3.5 & 10.5 & 36.4 & 30.1 & 100 & \\
\hline \multirow{2}{*}{ Observation } & $\mathrm{f}$ & 2 & 50 & 50 & 33 & 8 & 143 & \multirow{2}{*}{3.81} \\
& $\%$ & 1.4 & 35.0 & 35.0 & 23.1 & 5.6 & 100 & \\
\hline \multirow{2}{*}{ Map literacy } & $\%$ & 0.7 & 4.9 & 18.9 & 30.8 & 44.8 & 100 & \multirow{2}{*}{4.01} \\
& $\mathrm{f}$ & 8 & 23 & 33 & 54 & 25 & 143 & \multirow{2}{*}{3.69} \\
\hline
\end{tabular}

Data were then gathered on Social Studies teachers' self-perceived level of empathy, financial literacy, entrepreneurship, observation, and map literacy skills, which are aimed to be acquired in the Social Studies Curriculum. According to Table $2,42.0 \%$ of teachers perceived themselves at a "good" level for empathy skills, and their answers were the same (36.4\%) for financial literacy skills. It was also found that participating teachers thought themselves to be at an "inefficient" (35.0\%) and also at "moderate" (35.0\%) levels for teaching entrepreneurship skills; at a "very good" (44.8\%) level for observation skills; and at a "good" (37.8\%) level for map literacy skills. Therefore, it can be seen that a majority of teachers perceived themselves as being at "good" or "very good" levels for empathy, financial literacy, observation, and map literacy skills. Finally, teachers considered themselves at an "inefficient" level concerning the entrepreneurship skill.

Table 3

Social Studies Teachers' Self-Efficacy Opinions about Basic skills in the Social Studies Program

\begin{tabular}{|c|c|c|c|c|c|c|c|c|}
\hline Basic Skills & & $\begin{array}{c}\text { Very } \\
\text { nefficient }\end{array}$ & $\begin{array}{c}\text { Inefficie } \\
\text { nt }\end{array}$ & $\begin{array}{c}\text { Moderat } \\
\mathrm{e}\end{array}$ & Good & $\begin{array}{l}\text { Very } \\
\text { good }\end{array}$ & Total & $\overline{\mathrm{x}}$ \\
\hline \multirow{2}{*}{ Legal literacy } & $\mathrm{f}$ & 27 & 33 & 29 & 24 & 30 & 143 & \multirow{2}{*}{4.27} \\
\hline & $\%$ & 18.9 & 23.1 & 20.3 & 16.8 & 21.0 & 100 & \\
\hline \multirow{2}{*}{ Communication } & $f$ & 5 & 8 & 33 & 43 & 54 & 143 & \multirow{2}{*}{3.97} \\
\hline & $\%$ & 3.5 & 5.6 & 23.1 & 30.1 & 37.8 & 100 & \\
\hline \multirow{2}{*}{ Cooperation } & $f$ & 2 & 23 & 50 & 49 & 19 & 143 & \multirow{2}{*}{3.43} \\
\hline & $\%$ & 1.4 & 16.1 & 35.0 & 34.3 & 13.3 & 100 & \\
\hline \multirow{2}{*}{$\begin{array}{l}\text { Recognizing } \\
\text { stereotypes and } \\
\text { prejudice }\end{array}$} & $\mathrm{f}$ & 17 & 24 & 33 & 44 & 25 & 143 & \multirow[b]{2}{*}{3.71} \\
\hline & $\%$ & 11.9 & 16.8 & 23.1 & 30.8 & 17.5 & 100 & \\
\hline \multirow{2}{*}{ Using evidence } & $f$ & 39 & 17 & 30 & 27 & 30 & 143 & \multirow{2}{*}{3.53} \\
\hline & $\%$ & 27.3 & 11.9 & 21.0 & 18.9 & 21.0 & 100 & \\
\hline
\end{tabular}


Results related to the opinions of Social Studies teachers about their selfefficacy levels in the basic skills of the Social Studies program or curriculum are presented in Table 3 above. According to Table 3, it can be inferred that the majority of teachers considered themselves to be at an "inefficient" (23.1\%) level for the legal literacy skills. However, teachers perceived themselves to be at a "very good" (37.8\%) level for communication skills; at a "medium" (35.0\%) level for cooperation skills; at a "good" (30.8\%) level for recognizing stereotypes and prejudices skills; and at a "very poor" (27.3\%) level for using evidence skills. Therefore, it can be said that a majority of teachers saw themselves at either an "inefficient" or "very inefficient" level regarding tlegal literacy and using evidence skills, whereas they reported themselves as being at "moderate" or "good" levels for communication, co-operation, and recognizing stereotypes and prejudices skills.

Table 4

Social Studies Teachers' Self-Efficacy Opinions about Basic Skills of the Social Studies Program

\begin{tabular}{llccccccc}
\hline Basic Skills & & $\begin{array}{c}\text { Very } \\
\text { inefficient }\end{array}$ & $\begin{array}{c}\text { Inefficie } \\
\text { nt }\end{array}$ & Moderate & Good & $\begin{array}{c}\text { Very } \\
\text { good }\end{array}$ & Total & \multirow{2}{*}{} \\
\hline Decision & $\mathrm{f}$ & 1 & 24 & 29 & 50 & 39 & 143 & \multirow{2}{*}{3,41} \\
making & $\%$ & 0.7 & 16.8 & 0.3 & 35.0 & 27.3 & 100 & \multirow{2}{*}{ ( } \\
\hline Location & $\mathrm{f}$ & 10 & 21 & 39 & 46 & 27 & 143 & \multirow{2}{*}{3.55} \\
analysis & $\%$ & 7 & 14.7 & 27.3 & 32.2 & 18.9 & 100 & \\
\hline Media & $\mathrm{f}$ & 27 & 19 & 15 & 38 & 44 & 143 & \multirow{2}{*}{3.12} \\
literacy & $\%$ & 18.9 & 13.3 & 10.5 & 26.6 & 30.8 & 100 & \\
\hline Perceiving & $\mathrm{f}$ & 8 & 47 & 37 & 21 & 30 & 143 & \multirow{2}{*}{3.53} \\
space & $\%$ & 5.6 & 32.9 & 25.9 & 14.7 & 21.0 & 100 & \\
\hline \multirow{2}{*}{ Self-control } & $\mathrm{f}$ & 6 & 25 & 33 & 44 & 35 & 143 & \multirow{2}{*}{3.71} \\
& $\%$ & 4.2 & 17.5 & 23.1 & 30.8 & 24.5 & 100 & \\
\hline
\end{tabular}

The results related to Social Studies teachers' opinions about their self-efficacy in the basic skills of the Social Studies program (including decision-making, location analysis, media literacy, perceiving space, self-control skills) are presented in Table 4 above.

According to the results, it can be seen that a majority of teachers perceived themselves as being at a "good" (35\%) level for decision-making skills, and at a "good" (32.2\%) level for location analysis skills. Furthermore, they perceived themselves as being at a "very good" (30.8\%) level for media literacy skills; at an "inefficient" (32.9\%) level for perceiving space skills; and at a "good" (30.8\%) level for self-control skills. It was also found the majority of teachers perceived themselves as being at either "good" or "very good" levels for decision-making, location analysis, media literacy, and self-control skills, although at an "inefficient" level for perceiving space skills. 
SSeker, M. (2021). An Investigation into Social Studies Teachers'Self-Efficacy Perceptions about Basic..

Table 5

Social Studies Teachers' Self-Efficacy Opinions about Basic skills in the Social Studies Program

\begin{tabular}{|c|c|c|c|c|c|c|c|c|}
\hline Basic Skills & & $\begin{array}{c}\text { Very } \\
\text { ineffici } \\
\text { ent }\end{array}$ & $\begin{array}{c}\text { Ineffici } \\
\text { ent }\end{array}$ & $\begin{array}{l}\text { Mod } \\
\text { erate }\end{array}$ & $\begin{array}{c}\text { Goo } \\
\text { d }\end{array}$ & $\begin{array}{l}\text { Very } \\
\text { good }\end{array}$ & Total & $\overline{\mathbf{x}}$ \\
\hline \multirow{2}{*}{ Political literacy } & $\mathrm{f}$ & 37 & 39 & 39 & 10 & 18 & 143 & \multirow{2}{*}{3.06} \\
\hline & $\%$ & 25.9 & 27.3 & 27.3 & 7 & 12.6 & 100 & \\
\hline \multirow{2}{*}{ Problem solving } & $f$ & 10 & 15 & 28 & 47 & 43 & 143 & \multirow{2}{*}{3.89} \\
\hline & $\%$ & 7 & 10.5 & 19.6 & 32.9 & 30.1 & 100 & \\
\hline \multirow{2}{*}{ Social participation } & $\%$ & 8 & 7 & 44 & 38 & 46 & 143 & \multirow{2}{*}{3.09} \\
\hline & $\mathrm{f}$ & 5.6 & 4.9 & 30.8 & 26.6 & 32.2 & 100 & \\
\hline \multirow{2}{*}{$\begin{array}{l}\text { Drawing and } \\
\text { interpreting tables, } \\
\text { graphics, and } \\
\text { diagrams }\end{array}$} & $\%$ & 21 & 44 & 24 & 29 & 25 & 143 & \multirow[b]{2}{*}{3.43} \\
\hline & $\mathrm{f}$ & 14.7 & 30.8 & 16.8 & 20.3 & 17.5 & 100 & \\
\hline \multirow{2}{*}{$\begin{array}{l}\text { The correct, beautiful, } \\
\text { and effective use of } \\
\text { Turkish }\end{array}$} & $\%$ & 2 & 37 & 29 & 28 & 47 & 143 & \multirow[b]{2}{*}{3.51} \\
\hline & $\mathrm{f}$ & 1.4 & 25.9 & 20.3 & 19.6 & 32.9 & 100 & \\
\hline \multirow{2}{*}{ Innovative thinking } & $\%$ & 39 & 29 & 46 & 2 & 27 & 143 & \multirow{2}{*}{357} \\
\hline & $\mathrm{f}$ & 27.3 & 20.3 & 32.2 & 1.4 & 18.9 & 100 & \\
\hline $\begin{array}{l}\text { Perception of time } \\
\text { and chronology }\end{array}$ & $\begin{array}{l}\% \\
\mathrm{f}\end{array}$ & $\begin{array}{c}28 \\
19.6\end{array}$ & $\begin{array}{c}19 \\
13.3\end{array}$ & $\begin{array}{c}51 \\
35.7\end{array}$ & $\begin{array}{c}17 \\
11.9\end{array}$ & $\begin{array}{c}28 \\
19.6\end{array}$ & $\begin{array}{l}143 \\
100\end{array}$ & 3.59 \\
\hline
\end{tabular}

Table 5 above presents the teachers' opinions about the following basic skills of the program: political literacy, problem solving, social participation, drawing and interpreting tables, graphics, and diagrams, using Turkish correctly, beautifully and effectively, innovative thinking, and perception of time and chronology.

The majority of teachers perceived themselves as being at either an "inefficient" (27.3\%) or "moderate" (27.3\%) level for political literacy skills; at a "good" (32.9\%) level for problem-solving skills; at a "very good" (32.2\%) level for social participation skills; at an "inefficient" (30.8\%) level for drawing and interpretation of tables, graphics, and diagrams skill; at a "very good" (32.9\%) level in the correct, beautiful and effective use of Turkish; and at a "moderate" level in both the innovative thinking (32.2\%) and the perception of time and chronology $(35.7 \%)$ skills. The results showed the majority of teachers saw themselves as being at either a "good" or "very good" level for skills related to problem solving, social participation, and the correct, beautiful and effective use of Turkish. Comparatively, they perceived themselves as being at an "inefficient" or "moderate" level for political literacy, drawing and interpreting tables, graphics, and diagrams, innovative thinking, and perception of time and chronology skills.

\section{Result and Discussion}

In the 2018 Social Studies Program or Curriculum, it was determined that "skillbased" and "student-centered" approaches should be added in addition to maintaining a "unit-based approach" (Güldalı, 2017). Accordingly, this study was carried out to determine the self-efficacy status of teachers regarding those basic skills included in 2018 Social Studies Curriculum. The following results were found. 
One of the aims of the 2018 Social Studies Curriculum is that the following 27 skills included in the program should be gained: “...research, environmental literacy, perception of change and continuity, digital literacy, critical thinking, empathy, financial literacy, entrepreneurship, observation, map literacy, Legal literacy, communication, collaboration, stereotype and recognizing prejudice, using evidence, decision making, location analysis, media literacy, perceiving space, selfcontrol, political literacy, problem solving, social participation, drawing and interpreting tables, graphics and diagrams, the correct, beautiful and effective use of Turkish, innovative thinking and perception of time and chronology." (Milli Eğitim Bakanlığı (MEB), 2018).

All these results reveal that the majority of the teachers perceived themselves as being inefficient for the following skills: research, perceiving change and continuity, critical thinking, entrepreneurship, legal literacy, collaboration, using evidence, perceiving space, political literacy, drawing and interpreting tables, graphics, and diagrams, innovative thinking, and perception of time and chronology.

Comparatively, teachers thought themselves to be at a "very good" or "good" level for environmental literacy, digital literacy, empathy, financial literacy, observation, map literacy, communication, stereotypical judgment and prejudice, decision making, location analysis, media literacy, self-control, problem solving, social participation, and the correct, beautiful and effective use of Turkish skills

Teachers who participated in the current study were asked about their selfefficacy status in the basic skills included in the Social Studies curriculum. According to the findings, teachers accepted themselves as being "good" at communication, empathy, and problem-solving skills. It may be possible for teachers who see themselves as "good" in these basic skills, to take measures by using different strategies, methods, and techniques in their teaching and training processes. To do so will ensure that these skills will create positive effects on students. Communication skills have an important place in Social Studies education, which is a Human Studies field. In a research study conducted on students and teachers, the importance of the communication skill was expressed with the concepts of "understanding, social unity, and peace" (Çelikkaya et al., 2019). Empathy skills were also argued by students and teachers as being important to ensure that individuals in society understand one another to ensure the peaceful continuation of society. Furthermore, the same study found that the students and teachers mentioned the reasons for problem solving skills to overcome the problems encountered in life, helping people and gaining social personality. In addition, just as some studies show that teachers are efficient in basic skills, some other studies indicate that implementing different strategies may lead to more successful learning processes (Akgün \& Çetin, 2018; Çoban \& Akşit, 2018; Güldalı, 2017; Öztürk \& Mutlu 2017; Tay, 2017).

The majority of the Social Studies teachers who participated in this study reported they were at a "good" or "moderate" level in the research, environmental literacy, perception of change and continuity, and digital literacy skills, but also at an "inefficient" level in their critical thinking skills. It is very important for students to have sufficient research skills so that they are able to access the correct information using evidence such as information, documents, archives, and records, 
and that they do so with the spirit of a researcher. Furthermore, it is important that they gain the critical thinking skills. Although it was concluded in this study that teachers found themselves efficient in research, environmental literacy, perception of change and continuity, and digital literacy skills, there are several other studies (e.g. Öztürk \& Mutlu, 2017) in which teachers stated that they did not find themselves to be efficient.

In the current study, Social Studies teachers stated that they saw themselves as at a "moderate" level in the environmental literacy skill, and it can be said that this result is in line with the results of some previous studies (e.g. Artun et. al., 2013). There could be several reasons as to why teachers' perception of themselves at a "moderate" level concerning the environmental literacy skill. In his study, Karatekin's (2012) emphasizes that the environmental literacy skill in Social Studies textbooks is predominantly at the knowledge level, while it remains at lower levels regarding the behavior dimension. Therefore, it can be said that the findings of the current research are in line with those by Karatekin (2012). It was found that most of the Social Studies teachers who participated in the current study regard themselves as "good" or "medium" in their perception of change and continuity skills. There are also different research studies (Çelikkaya, 2011; Özen \& Sağlam, 2010 ) that underline the importance of the perception of change and continuity skill for effective social studies teaching. The fact that teachers in the present study perceive themselves as being at a "good" or "moderate" level in the digital literacy skill can make us think that teachers can also be efficient in other skills. Relating 16 of the 27 skills included in the 2018 Social Studies Teaching Program with digital citizenship can be considered an important finding in terms of digital citizenship (Turan \& Karasu-Avcl, 2018).

In the current study, Social Studies teachers perceived themselves as being at a "good" level concerning the financial literacy skills. Analysis of the Social Studies curriculum, which was revised in 2018, reveals that financial literacy is included within the scope of production, distribution, and consumption learning (Yalçınkaya \& Er, 2019). On examination of compulsory courses, it can be seen that most of the learning outcomes regarding financial literacy are included in the Social Studies course (Güvenç, 2017). Therefore, it may be important for teachers to train their students with different and effective strategies, methods, and techniques in the financial literacy skill.

It was seen that the teachers participating in the study considered themselves to be at an "inefficient" and "moderate" level regarding their teaching of entrepreneurship skills. Accordingly, teachers generally saw themselves as having a moderate proficiency level for this skill. The findings of other studies (Çermik \& Şahin, 2015) align with this result, and emphasize that teachers should have sufficient readiness to train their students with an entrepreneurial spirit (Çelikkaya, 2011; Öztürk \& Mutlu, 2017).

It is understood that the majority of teachers considered themselves to be at a "very good" level for observation and map literacy skills. Observation skills are specifically emphasized in some units of the Social Studies curriculum (e.g. People, Places and Environments). The learning domain People, Places and Environments 
aims to provide students with research, environmental literacy, perception of change and continuity, observation, map literacy, and perceiving space skills across all grade levels in which the Social Studies course is taught (MEB, 2018).

The findings of the current research show that the majority of teachers considered themselves to be "inefficient" in the basic skill of law and political literacy. Law is one of the Social Sciences disciplines. One of the most important goals of the 2018 Social Studies program is to make this skill permanent through different learning methods and techniques in order to raise the generations of students who both know and know how to protect their rights. The Social Studies course comprises nine learning domains. On examination of these learning domains, it can be seen that six are related to law and political literacy. The fact that most of the learning domains are related to legal literacy and political literacy is undoubtedly proof of the importance of Social Studies course in raising effective citizens. Of the six learning domains, two are directly related to legal literacy, one is directly related political literacy, and three are directly related to both law and political literacy (Kara \& Tangülü, 2017). It is essential that teachers develop their knowledge on "legal and political literacy". Therefore, more effective steps can be taken to enable children to internalize this skill. In addition, the majority of teachers considered themselves to be at a "good" level for the basic skills of recognizing stereotypes and prejudices.

Another important skill of the 2018 Social Studies program is to recognize stereotypes and prejudices, because stereotypes and prejudices are two important sources of othering trends. These factors, which comprise one of the most important obstacles to individuals' free and objective thinking, are very dangerous factors in regard to critical thinking. They affect individuals' perceptions and can prevent these individuals from analyzing their perceptions correctly and looking at events objectively; this is because individuals form their own thoughts regarding the perceptions, knowledge, and thoughts that belong to others, often acting on baseless and unfounded information as a result (Kocadağ, 2019). While the Global Connections learning domain is being taught, it is stated that "cooperation with values such as peace and respect, problem solving with skills such as recognizing stereotypes and prejudices should be acquired by students" (MEB, 2018). This indicates that it is important for teachers to see themselves as being efficient in the basic skill of recognizing stereotypes and prejudices. Other studies in the literature also emphasize the importance of this skill (Beldağ \& Teymur, 2018; Tay, 2017).

It is understood that a majority of teachers considered themselves as "inefficient" for using evidence as a basic skill. There are research studies emphasizing that educators should pay attention to the use of evidence for effective teaching in the Social Studies teaching process (Işık, 2008; Sağlam \& Bilgiç, 2018; Tangülü \& Çidacı, 2016).

The current study also shows that Social Studies teachers found themselves to be at a "good" or "very good" level in some of the basic skills in the program, specifically, decision-making, location analysis, media literacy and self-control.

Decision making is important for students to make fast, objective, rational, and logical decisions when encountering different environments and emotions. Some 
research on this subject have shown that different results are encountered during the implementation periods of constructivism. For example, in a study conducted by Demircioglu (2009), it was found that teachers were not at an efficient level in decision making, however, in the current study, conducted in 2019, it was determined that teachers perceived themselves at efficient level. This finding is supported by different studies (e.g. Gelen, 2002). In addition, some skills should be gained in teaching geography subjects, which is one of the disciplines used by Social Studies. Location analysis skill, as one of these skills, is an important skill in terms of "People, Places and Circles" learning domain. Even though not directly included in the specific objectives in Social Studies curriculum, there are expressions that may include Geographic Information Technologies. Geographical Information Technologies can be supported with the skills and values given in the curriculum. These skills and values include the following skills: research, perception of change and continuity, digital literacy, map literacy, location analysis, perceiving space, drawing and interpretation of tables, graphics and diagrams, and perception of time and chronology, and are scientific (İbret \& Yllmaz, 2018). There are also some studies (Ablak \& Aksoy, 2018; Akbaş \& Toros, 2017; Aktürk et al., 2013; Çelikkaya et al., 2019) on the importance of the "good" level of self-efficacy in the location analysis skill as also found to be stated by teachers involved in this study.

Regarding media literacy, the majority of teachers who participated in this research defined themselves as being at a "very good" level. Special emphasis is placed on media literacy, which concerns a proper understanding of communication today within the Turkey's National Education system. Therefore, both in the present and prospective context, it is important that particular pedagogical definition be given to 'action areas' within the media sector, and that students gain a proper understanding of the relevant skills in this regard. For this reason, the fact that the teachers in the current study defined their self-efficacy in media literacy skill as "very good" is in line with other studies in the field (Altun, 2012; Çepni et al., 2015; Deveci \& Çengelci, 2008). Furthermore, teachers reported they perceived themselves as being "inefficient" in the basic skill of perceiving space. Considering that the ability to perceive space is also related to the program's "People, Places and Environments" learning domain, it is seen that many skills in this learning domain (research, perceiving change and continuity, digital literacy, map literacy, location analysis, perceiving space, drawing and interpreting tables, graphics and diagrams, perception of time and chronology) are aimed to be acquired. There are important studies on the acquisition of this skill (Ablak \& Aksoy, 2018; Safi, 2010).

Regarding the basic skill of social participation included in the program, it was determined that the majority of teachers considered themselves "very good", and many studies on this issue (Çelikkaya, 2011; Çubukçu \& Gültekin, 2006; Philanthropist, 2010) emphasize the importance of this skill. Therefore, the fact that Social Studies teachers have a certain social participation skill may cause students to reach important levels in this skill. In addition, it was understood that teachers considered themselves "inefficient" in the skill of drawing and interpreting tables, graphics and diagrams. The analysis of the program shows that the skill of drawing and interpreting tables, graphics and diagrams is given importance in science and social studies (MEB, 2009A; 2009B; MEB, 2019). However, the fact that Social 
Studies teachers were found to be in this skill may be due to the fact that the skills the drawing and interpreting tables, graphics and diagrams skill requires are especially quantitative; this is because graphics are accepted as an important representation type in mathematics (Erbilgin et al., 2015).

In the current study, it is seen that teachers regarded themselves as "very good" regarding the using Turkish correctly, beautifully and effectively skill. Other studies emphasize that teachers should feel comfortable when communicating with students in order for effective learning to occur (Kaymakçı, 2013; Saracaloğlu et al., 2001; Deniz \& Tuna, 2016). Therefore, the proficiency of teachers in this subject may be influential in ensuring students pay more attention to Turkish and that they form reading habits.

The results show that teachers who participated in this study saw themselves as being at a "moderate" level regarding the teaching of innovative thinking and perception of time and chronology skills. Accordingly, teachers stated that they had a moderate efficacy level in this skill. The results of several other studies in the field (Çelikkaya et al., 2019; Hacat \& Demir, 2019) are in line with this result, and the need for teachers to have efficient readiness for educating students with an entrepreneurial spirit is emphasized. The Social Studies curriculum that became effective in 2005 by MEB adopted a thematic approach and is built on four bases: knowledge, skill, attitude, and value and ethics. One of these themes, Innovative thinking, is considered an important step (MEB, 2011). Additionally, it can be stated that Social Science teachers have a special interest regarding the perception of time and chronology skill, especially in the teaching of history. It is very important for such educators to choose student-centered strategies, methods, principles, and materials when teaching the ability to perceive time and chronology, as well as benefit from out-of-school observation trips in order to not compress the education between four walls of a classroom (Sağlam et al., 2015).

As shown in the current study, teachers' acceptance of themselves as "moderate" regarding the ability of perception of time and chronology may imply that there are difficulties in concretizing the history issues in Social Studies by teachers, which may negatively affect students' academic performance. Regarding the acquisition of the basic skills included in the program, the implementation of strategies, methods and techniques that are appropriate for learning styles and individual differences among social studies teachers is very important regarding the provision of permanence of learning. The measures to be taken in this framework will enable the students to enjoy learning more and enrich the process at the point of permanent learning.

\section{Suggestions}

- Different learning environments should be created in order for students to acquire basic skills related to Social Studies, and learning environments that are appropriate to specific learning styles should be created for all literacy skills (environmental literacy, digital literacy, financial literacy, map literacy, legal literacy, media literacy, political literacy). In addition, theoretical studies should be conducted using experts who are experts in the field and effective teaching processes should be followed through use and application of experimental research. Effective in-service training should be provided to 
enable students to gain environmental, digital, financial, map, legal, media, and political-literacy skills.

- In order for the skills to be effectively acquired, education and training activities should be implemented that are appropriate for the individual differences and different learning styles of students, and effective measures should be taken by examining local and universal practices.

- All programs made previously and subsequently revised should also be examined, success in these skills, and the other approaches equivalent to these skills, should also be determined. Necessary studies should be carried out in order to prevent the repeating of experienced deficiencies, and necessary plans should be made within the framework of pedagogical insights, by identifying the weaker and stronger sides of the program.

- Skills should be linked to sensitivity in regard to culture and value, and effective measures should be taken to produce realistic policies by identifying these deficiencies.

- It is important to act according to the near-to-far principle so that students can acquire Social Studies' geography subjects in a qualified manner. Therefore, it should be ensured that the materials used in learning processes are up-to-date, effective, and qualified.

- In order to educate students into becoming good history readers regarding the acquisition of history subjects, abstract topics must be concretized, and auditory and visual materials used effectively.

- Students should be encouraged to participate in real learning environments, and local and oral history practices should be frequently used in the acquisition of historical skills.

- If Social Studies teachers follow the literature on skills and improve themselves, they can be more efficient pedagogically. In this way, lecturing processes can be more qualified and effective. Teachers training in skills can be more effective on students' success.

- Working principles of other disciplines comprising Social Studies should be followed, and current and effective measures should be taken in accordance with the students' levels.

\section{References}

Ablak, S., Aksoy, B. (2018). Investigation of student perceptions related to spatial perception skills in social studies program. Turkish Studies, 13(11), 1-32.

Akbaş, Y., Toros, S. (2017). Analysis of preservice social science teachers' perceived selfefficacy for spatial technologies according to a set of variables. Uluslararası Sosyal Araştırmalar Dergisi, 10, 54.

Aktürk, V., Yazıcı, H., Bulut, R. (2013). The effects of the use of animations and digital maps in social studies on students' spatial perception skills. Marmara Coğrafya Dergisi, 28, $1-17$. 
Altun, A. (2012). The media literacy education in the social studies curricula in Canada. 1, 230-244.

Arseven, A. (2016). Self-Efficacy: a concept analysis. Turkish Studies, 11(19), 63-80.

Artun, H., Uzunöz, A., Akbaș, Y. (2013). The evaluation of the factors affecting the levels of environmental literacy of social science prospectıve teachers. Pamukkale Üniversitesi Eğitim Fakültesi Dergisi, 34 (2), 1-14.

Aydemir, M., Adamaz, K. (2017). An analysis of achievements and activities included in the secondary school social sciences curriculum from the perspective of common and course-specific skills. International Journal of Field Education, 3(2), 37-59.

Bandura, A. (1986). Social foundations of though tandaction: a social cognitive theory. Englewood Cliffs, NJ: Prentice-Hall.

Bandura, A. (1995). Self-Efficacy in changing societies. Cambridge: Cambridge University Press.

Beldağ, A., Teymur, N. (2018). Multicultural education in the curriculum of social studies: a content analysis. TAY Journal, 2(2), 117-129.

Büyüköztürk, Ş. (2012). Sosyal bilimler için veri analizi el kitabı. Ankara: Pegem Akademi.

Çelikkaya, T. (2011). Transmission level of skills in the social studies curriculum: Theacher's opinions. Kastamonu Eğitim Dergisi, 19 (3), 969-990.

Çelikkaya, T., Yıldırım, T. ve Kürümlüoğlu, M. (2019). Ability hierarchies, reasons and recommendations of students and social studies teachers regarding ability in social studies curriculum. Manas Sosyal Araştırmalar Dergisi, 8(1), 113-134.

Çermik, F., Şahin, İ. F. (2015). Investigation of Social Entrepreneurship Characteristics of Pre-service Social Studies Teachers in Terms of Various Variables. Current Research in Education, 1(2), 76-88.

Çepni, O., Palaz, T., Ablak, S. (2015). Examining prospective social sciences teachers' level of media and television literacy according to different variables. Turkish Studies, 10(11), 431-446.

Çoban, O., Akşit, İ. (2018). Comparison of 2005 and 2017 Social Studies Curriculum in terms of learning area, acquisition, concept, value and skill. Journal of History Culture and Art Research, 7(1), 479-505.

Çubukçu Z., Gültekin M. (2006). Social skills that need to be gained by primary school students. Bilig, 37, 154-174.

Demircioğlu, İ. H. (2009). Perceptions of history teachers about historical thinking skills. Milli Eğitim Dergisi, 184, 228-239.

Deniz, S., Turhan Tuna, S. (2016). Evaluation of the pre-service Turkish and classroom teachers' competencies in terms of effective use of Turkish. Uluslararası Sosyal Araştırmalar Dergisi. 9 (47).

Deveci, H., Çengelci, T. (2008). A look to the media literacy by social studies teacher candidates. Yüzüncü Yıl Üniversitesi Eğitim Fakültesi Dergisi, 5(2), 25-43.

Erbilgin, E., Arıkan, S., Yabanlı H. (2015). Assessing Line Graph Comprehension and Construction Skills. Ahi Evran Üniversitesi Kırșehir Eğitim Fakültesi Dergisi (KEFAD), 16(2), 43-61.

Erden, M. (n.d.). Sosyal bilgiler öğretimi. Ankara: Alkım Kitapçılık-Yayıncılık. 
Seker, M. (2021). An Investigation into Social Studies Teachers'Self-Efficacy Perceptions about Basic..

Gelen, İ. (2002). The Evalution of fourth grade elementary school teachers' competences about teaching thinking skills in social studies course. Çukurova Üniversitesi Sosyal Bilimler Enstitüsü Dergisi, 10(10), 100-96.

Güldalı, Ş. U. (2017). Comprasion of 2009 and 2017 life science course curricula. Türk Akademik Yayınlar Dergisi, 1(1), 76-98.

Güvenç, H. (2017). Financial literacy in Turkish formal education curriculum. Elementary Education Online, 16(3), 935-948.

Hacat, S. O., Demir, F. B. (2019). Evaluation of the social studies course curriculum in terms of sustainable development education. Diyalektolog Ulusal Sosyal Bilimler Dergisi, 22, 211-225.

Kara, H., Tangülü, Z. (2017). Case study on legal and political literacy at the social studies curriculum. Araştırma ve Deneyim Dergisi 2(1).

Karatekin, K., Aksoy, B. (2012). Examination of teacher candidates of social studies' environmental literacy level in terms of various variables. Turkish Studies, 7(1), 14231438.

Kaymakçı, S. (2013). The usage situation of oral and written literary works in social studies textbooks. Dicle Üniversitesi Ziya Gökalp Eğitim Fakültesi Dergisi, 20, 230-255.

Kotaman, H. (2008). Self-Efficacy belief and enhancement of learning performance. Eğitim Fakültesi Dergisi, 21(1), 111-133.

Kocadağ, Ş. (2019). Evaluation of social studies secondary school curriculum in terms of othering phenomenon. Yayımlanmamış yüksek lisans tezi, İbrahim Çeçen Üniversitesi, Ağrı.

Işı, H. (2008). Evidence based learning model in primary school, social studies lesson: An action research. Yayımlanmamış yüksek lisans tezi, İstanbul.

İbret, B. Ü. ve Yılmaz, O. (2018). The place of geographical information technologies in social sciences course books and teaching program. International Geography Education Symposium (8- 10 November). Nevșehir.

Ministry of National Education. (2009A). Elementary mathematics course (grades 1-5) curriculum. Ankara: MEB-Talim Terbiye Kurulu Başkanlığı Yayınları. Retrieved from http://ttkb.meb.gov.tr

Ministry of National Education (2009B). Primary education social studies lesson 7th grade program. Middle school mathematics lesson (5th, 6th, 7th and 8th grades) curriculum. Retrieved from http://ttkb.meb.gov.tr

Ministry of National Education (2013A). Middle school mathematics lesson (5th, 6th, 7th and 8th grades) curriculum. Retrieved from http://ttkb.meb.gov.tr

Ministry of National Education (2013B). Primary education institutions science course (3rd, 4th, 5th, 6th, 7th and 8th grades) curriculum. Retrieved from http://ttkb.meb.gov.tr/

Ministry of National Education (2011). The characteristics of a 21st century student. Ankara: Milli Eğitim Bakanlığı Eğitimi Araştırma ve Geliştirme Dairesi Başkanlığı. Retrieved from https://www.meb. gov.tr/earged/earged/21.\%20yy_og_pro.pdf

Ministry of National Education (2018). Social studies curriculum. Retrieved from http://ttkb.meb.gov.tr/

Özen, R., Sağlam, H. İ. (2010). Perception of primary students on change and continuity. Akademik Bakış Dergisi, 22. 
Öztürk, M., Mutlu, N. (2017). How do we teach the skills and values in social sciences and history courses? Sakarya University Journal of Education, 7(3), 552-563.

Saracaloğlu, S., Özkütük, N., Silkü, A. (2001). Communication skills of university students. X. Ulusal Eğitim Bilimleri Kongresi Bildiriler Kitabı içinde (s.1754-1762). Bolu: Abant İzzet Baysal Üniversitesi.

Sağlam, H. İ., Tınmaz, E., Hayal, M. A. (2015). A phenomenological perspective on teaching experiences of perception skills of "time and chronology" of classroom teachers. Turkish History Education Journal, 4(1), 49-66.

Sağlam, H. İ., Bilgiç, S. (2018). Investigation of the effect of evidence based learning in primary school 4th grade social studies lesson. Sakarya University Journal of Education, 8(2), 60-71.

Safi, H. (2010). Teachers' opinions about the spatial cognition skills. Yayımlanmamış yüksek lisans tezi, Marmara Üniversitesi Eğitim Bilimleri Enstitüsü, İstanbul.

Sever, R., Yalçınkaya, E., Mazman, F. (2009). An effective teaching method at studies teaching: dramatization. Atatürk Üniversitesi Sosyal Bilimler Enstitüsü Dergisi, 13(1), 155-166.

Sönmez, V., Alacapınar, F. G. (2011). Örneklendirilmiş bilimselaraştırma yöntemleri. Anı Yayıncilık. Ankara.

Tangülü, Z., Çıdacı, T. (2016). Using original sources while teaching topics of history in social sciences course. Sosyal Bilimler Dergisi, 6(11), 253-273.

Taşkın A., Memişoğlu, H. (2019). Evaluation of usage level of current issues in the textbooks of social studies. Kastamonu Ĕgitim Dergisi, 27(2), 599-610.

Tay, B. (2017). Comparison of 2005 social studies course curriculum and 2017 social studies course draft curriculum. International Journal of Eurasia Social Sciences, 8(27), 461487.

Tezbaşaran, A. A. (1997). Likert tipi ölçek hazırlama kılavuzu. Türk Psikologlar Derneği, Ankara

Turan, S., Karasu-Avcı, E. (2018). 2018 Sosyal bilgiler öğretim programı'nın dijital vatandaşlık bağlamında incelenmesi. Eğitim ve Yeni Yaklaşımlar Dergisi, 1(1), 28-38.

Yalçınkaya, E., Er, T. (2019). Financial literacy in social studies education. Nevșehir Hacı Bektaş Veli Üniversitesi SBE Dergisi, 9(1), 1-24.

\section{Biographical Statement}

Mustafa ŞEKER is an Associate Professor at the Faculty of Education in Yıldız Technical University, where he works at Department of Turkish and Social Sciences. His research interest includes Social Studies education, teaching history and learning styles, concept teaching. 